\title{
Testis-Specific Y-Encoded-Like Protein 2
}

National Cancer Institute

\section{Source}

National Cancer Institute. Testis-Specific Y-Encoded-Like Protein 2. NCI Thesaurus. Code C101299.

Testis-specific Y-encoded-like protein 2 (693 aa, $79 \mathrm{kDa}$ ) is encoded by the human TSPYL2 gene. This protein is involved in the assembly of nucleosomes. 